\title{
Individual Difference in Toxic Diffuse Goiters Assessed by Heme-based Specific Activity and Km Value ${ }^{\#}$
}

\author{
Yoshiaki HOSAKA ${ }^{*, 1}$, Teiko ISHII*,2 \\ Noriaki SUZUKI*,2, JUNTA TAKAMATSU**, \\ Shuzo HIRAKAWA***, AND ToIChIRo HOSOYA****** \\ *Faculty of Pharmaceutical Sciences, Chiba University, Chiba \\ 263, **The First Department of Medicine, Osaka Medical \\ School, Osaka 569, ***Third Department of Medicine, Okayama \\ University School of Medicine, Okayam 700, ****Faculty of \\ Industrial Science and Technology, Science University of Tokyo, \\ Chiba 278, Japan
}

\begin{abstract}
Thyroid peroxidase (TPO) was purified from each thyroid of 10 patients (experiment 1) and 4 patients (experiment 2) with toxic diffuse goiter by a simplified method with monoclonal anti-TPO antibody-assisted immunoaffinity column chromatography. The final preparations were used to measure the heme concentration based on the cyanide difference spectrum, and to determine the $\mathrm{Km}$ and $\mathrm{k}_{\text {cat }}$ values from double reciprocal plots in the assay employing guaiacol and iodide as the second substrates. The heme-based specific activities of TPO purified from thyroids in experiment 1 were higher than those in experiment 2, which were probably impaired by freezing-thawing, and those of porcine TPO previously reported. There were some differences in the kinetic properties between experiment 1 and experiment 2, but the individual differences within each group were relatively small, the values for $\mathrm{CV}$ (=SD/mean) being $0.16-0.48$.
\end{abstract}

Key words: Thyroid peroxidase, Toxic diffuse goiter, Heme content, Michaelis constant.

(Endocrine Journal 40: 141-148, 1993)

THE THYROID peroxidase (TPO) activity of patients with toxic diffuse goiters has been examined by several research groups [1-7]. The majority of the groups reported that the activity was enhanced in the toxic diffuse goiters, in accordance with histochemical observations in stimulated localization of the enzyme in endoplasmic reticulum and microvilli areas [6, 8, 9]. A quantitative increase in TPO is therefore believed

Received: July 17, 1992

Accepted: December 28, 1992

Correspondence to: Dr. Toichiro HOSOYA, 4-27-7 Tsuganodai, Wakaba-ku, Chiba, Chiba 264, Japan.

\# A preliminary report of portions of this work was presented at the 63rd Annual Meeting of the Japanese Biochemical Society on September 15th, 1990 (Abstract: Seikagaku 62: 724). ${ }^{1}$ Present address: Daiichi Seiyaku Co., Edogawa-ku, Tokyo 134. ${ }^{2}$ Present address: Nihon Medi-Physics Co., Sodegaura, Chiba 299-02. to be responsible for the high production of thyroid hormones in toxic diffuse goiters.

On the other hand, the protein-based specific TPO activity of the particulate fractions obtained from toxic diffuse goiters varied from thyroid to thyroid [7] and some hypothyroids had markedly low TPO activity per molecule compared with the normal value $[10,11]$. Thus, the possibility cannot be denied that some qualitative change as well as quantitative variation may occur in TPO in toxic diffuse goiters. To determine these changes, the enzyme must be purified to have its heme concentration determined. However, since the TPO content is very low in each thyroid and solublilization with detergents and proteases from the microsomes is a prerequisite for purification, it was difficult to purify the enzyme from a thyroid gland. Thus, the purification of TPO has been 
performed by starting from pooled thyroids of animals [12-15] and patients with toxic diffuse goiter [16]. However, recent improvement in conventional column chromatography [13-15] and monoclonal anti-TPO antibody-assisted affinity chromatography [17-20] has stimulated the development of more efficient procedures for purification of human TPO.

In the present study, we have attempted to improve the efficiency of purification of TPO by one-step conventional column chromatography followed by monoclonal antibody-assisted affinity column chromatography. Since the method requires only $15 \mathrm{~g}$ of thyroid tissue to obtain a final TPO preparation, the heme content of which can be determined, we could isolate TPO from each patient with toxic diffuse goiter and compare the catalytic properties on the basis of heme content.

\section{Materials and Methods}

\section{Materials}

Trypsin (1:300) was purchased from ICN NBC, Cleveland, OH, U.S.A. Soybean trypsin inhibitor (Type II) and 4-chloro-1-naphthol were from Sigma, St Louis, MO, U.S.A. CNBr-activated Sepharose was from LKB-Pharmacia Biotechnology, Uppsala, Sweden, DE52 (microgranular DEAE cellulose) was from Whatman International Ltd, Maidstone, England, the avidin-biotin-peroxidase complex was from Vector Laboratories Inc. Burlingame, CA, U.S.A. Sodium cholate and Tween 20 were from Nakarai Tesque Co., Kyoto, Freund's adjuvant was from DIFCO Laboratories, Detroit, Michigan, U.S.A. The cell culture medium used was RPMI 1640 medium obtained from Nissui Seiyaku Co., Tokyo. Bovine fetal serum was purchased from Wheaton Co., penicillin $G$ and streptomycin sulfate were from Meiji Seika Co., Tokyo and $7 \%$ sodium hydrogen carbonate was from Hikari Seiyaku Co., Osaka. Other reagents were of analytical grade obtained from Wako Pure Chemicals, Osaka.

\section{Thyroid tissues}

Patients with toxic diffuse goiter underwent partial thyroidectomy at Ito Hospital, Tokyo (10 patients, experiment 1) and Kuma Hospital, Kobe
(4 patients, experiment 2). Table 1 shows the clinical data for these patients. The thyroid tissues were frozen with dry ice and kept in the freezer at $-70^{\circ} \mathrm{C}$ until use.

Homogenization, fractionation of toxic diffuse goiter and assay for peroxidase activity in the mitochondriamicrosomes fraction

A part (usually $1 \mathrm{~g}$ ) of each toxic diffuse goiter was cut off in the frozen state and used for homogenization, fractionation and for peroxidase assay [22]. The remaining tissues were stored at $-70^{\circ} \mathrm{C}$ and used for purification of TPO by affinity column chromatography as described below. The peroxidase activity of the mitochondriamicrosomes obtained from the $1 \mathrm{~g}$ of thyroid tissue was measured, after treatment with cholate, by "ordinary assay" method using guaiacol and iodide as the second substrate as described previously [22].

Assay for guaiacol oxidation and iodide oxidation activities of TPO

For the guaiacol oxidation assay, the reaction mixture $(3.02 \mathrm{ml})$ contained $33 \mathrm{mM}$ guaiacol, 0.27 $\mathrm{mM} \mathrm{H} \mathrm{H}_{2} \mathrm{O}_{2}$ and $33 \mathrm{mM}$ sodium phosphate $(\mathrm{pH}$ 7.4), and for the iodide oxidation assay, it $(3.02 \mathrm{ml})$ contained $0.135 \mathrm{mM} \mathrm{H}_{2} \mathrm{O}_{2}, 4.95 \mathrm{mM}$ potassium iodide, and $33 \mathrm{mM}$ sodium phosphate ( $\mathrm{pH} 7.0)$. The reaction was started by adding $20 \mu \mathrm{l}$ of $\mathrm{H}_{2} \mathrm{O}_{2}$. When the mitochondria-microsomes were used as the enzyme source, they were treated with $0.7 \%$ cholate before the reaction as described [22]. The amount of enzyme which gave a change of 1.0 absorbance unit per second was taken as 1 unit and expressed as guaiacol unit (GU) or iodide unit (IU). To calculate the enzyme turnover number, an extinction coefficient of $5.57 \times 10^{3} \mathrm{M}^{-1} \mathrm{~cm}^{-1}$ was employed for oxidized guaiacol [23, 24] and $26 \times 10^{3} \mathrm{M}^{-1} \mathrm{~cm}^{-1}$ for the oxidized iodide, triiodide [25]. To analyze double reciprocal plots, the concentrations of the enzyme and the substrates were varied as described in each experiment.

Purification of TPO from each thyroid of patients with toxic diffuse goiter

A part of the frozen thyroid (about $15 \mathrm{~g}$ ) was 
Table 1. Clinical data for patients with toxic diffuse goiters

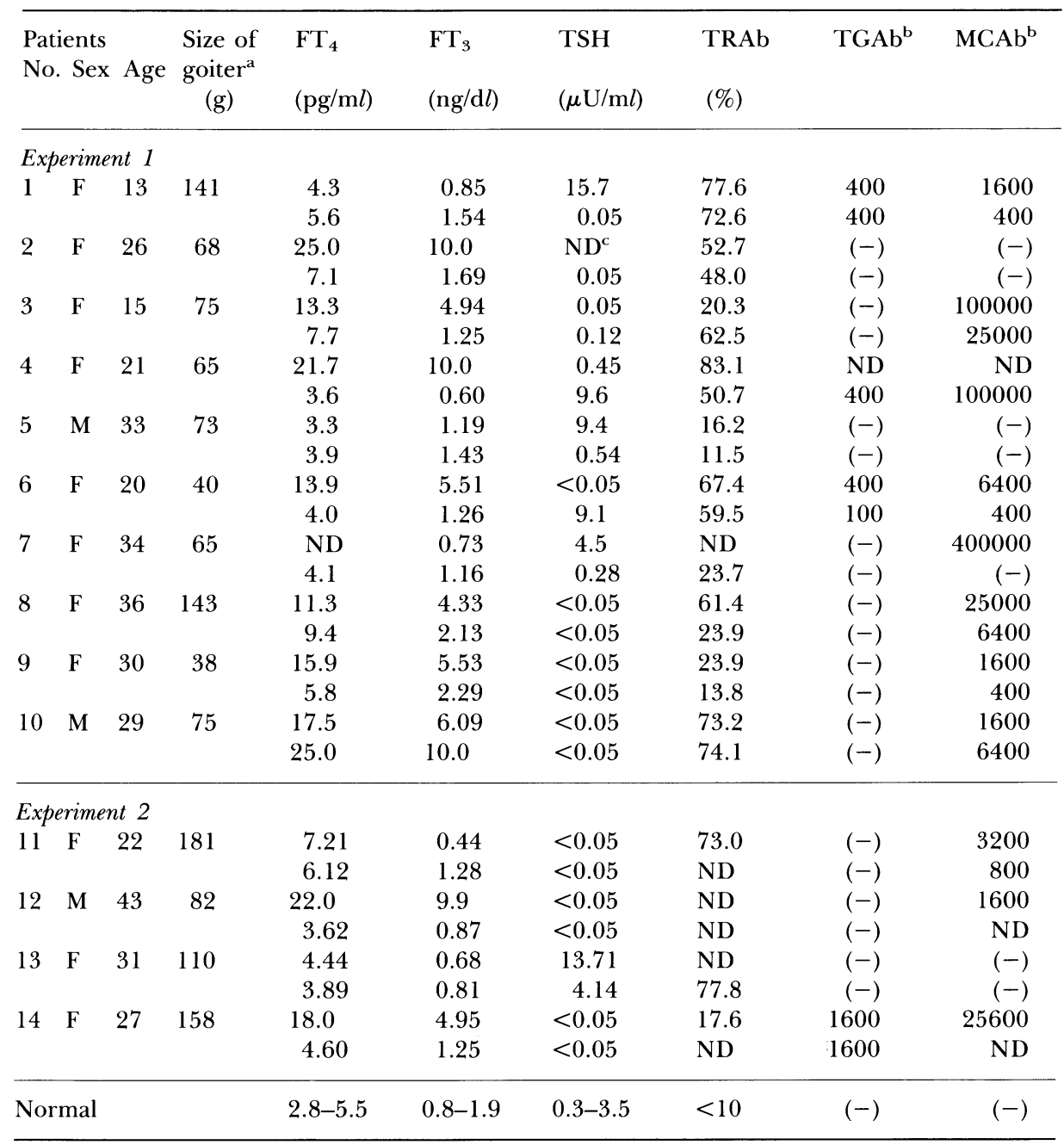

The data in the upper and lower lines of each patient indicate those obtained at the time of the first medical examination and the operation, respectively.

a: The size of goiters was estimated by the method described by Takamatsu et al. [21]. b: The level of the antibody is shown in titers. The sign (-) indicates that two-fold diluted serum does not react with thyroglobulin and microsomal proteins.

thawed, sliced and washed with $0.9 \% \mathrm{NaCl}$ containing $10 \mathrm{mM}$ phosphate buffer (phosphate buffered saline, PBS). After blotting with filter paper, the tissues were homogenized in about $45 \mathrm{ml}$ of $0.25 \mathrm{M}$ sucrose/PBS with Ultra-Turrax and the homogenate was centrifuged at $2000 \times \mathrm{g}$ for 10 min. The cytosol obtained was centrifuged at $105,000 \times \mathrm{g}$ for $60 \mathrm{~min}$ and the pellet (mitochondria-microsomes) was suspended in buffer A (PBS containing $10 \mathrm{mM} \mathrm{KI})(0.2-0.5 \mathrm{ml}$ per $\mathrm{g}$ tissue). After the protein concentration of the suspension was measured, an appropriate volume of buffer A was added to the suspension to make it contain 20 $\mathrm{mg}$ protein $/ \mathrm{ml}$, and the mixture was preincubated for $5 \mathrm{~min}$ at $37^{\circ} \mathrm{C}$. Then to the mixture, a trypsin $(1: 300)(10 \mathrm{mg} / \mathrm{ml})$ solution and a cholate $(10 \%)$ solution were added to make a concentration of $3 \%$ (3 mg trypsin (1:300) to every $100 \mathrm{mg}$ protein) and $0.5 \%$, respectively, followed by incubation for $60 \mathrm{~min}$ at $37^{\circ} \mathrm{C}$ [26]. At the end of incubation, a trypsin inhibitor $(10 \mathrm{mg} / \mathrm{ml})$ was added to obtain a trypsin:inhibitor ratio of $1: 1.5$ and the mixture was chilled for $15 \mathrm{~min}$. The supernatant was applied to a DEAE-cellulose column $(12 \times 80 \mathrm{~mm})$ which was previously equilibrated with buffer $A$, and the column was washed with buffer A until the 
absorbance at $280 \mathrm{~nm}$ of the eluate was below 0.1 . Gradient elution $(0-0.5 \mathrm{M} \mathrm{NaCl}$ in buffer $\mathrm{A}$ containing $0.1 \%$ cholate) was then performed and the active fractions were combined. The solution was centrifuged at $500 \times \mathrm{g}$ for $10 \mathrm{~min}$ several times in a Centriflow (CF 25 membrane, Amicon Div., W.R. Grace Co.) to concentrate the enzyme and to replace the medium with $10 \mathrm{mM}$ Tris- $\mathrm{HCl}(\mathrm{pH}$ 7.8) containing $0.1 \mathrm{mM} \mathrm{KI}, 0.5 \mathrm{M} \mathrm{KCl}$ and $0.1 \%$ cholate. The solution $(3-5 \mathrm{ml})$ was then applied to an anti-TPO antibody-associated Sepharose column which was prepared as described below, washed with $5 \mathrm{ml}$ of $0.1 \mathrm{M}$ borate buffer ( $\mathrm{pH} 9.0$ ) containing $0.1 \mathrm{mM} \mathrm{KI}, 1 \mathrm{M} \mathrm{KCl}$ and $0.5 \%$ cholate, and TPO was eluted with $0.1 \mathrm{M} \mathrm{NH}_{4} \mathrm{OH}$ containing $0.1 \mathrm{mM} \mathrm{KI}, 1 \mathrm{M} \mathrm{KCl}$ and $0.5 \%$ cholate. The active fractions eluted were pooled for ultrafiltration in a Centriflow at $500 \times \mathrm{g}$ for $10 \mathrm{~min}$ several times to replace the medium with $10 \mathrm{mM}$ buffer $\mathrm{A}$. The final preparation was usually yellow in color and about $3 \mathrm{ml}$ in volume. An aliquot of the solution was immediately subjected to cyanide difference spectrum analysis to determine the concentration of heme.

\section{Culture of hybridoma and preparation of affinity column}

Preparation of Hybridoma: Hybridoma cells producing the anti-TPO antibody were prepared as described previously [9, 20]. Thyroid microsomes solubilized with n-octyl- $\beta$-D-glucoside from toxic diffuse goiters were used as the antigen. Five $\mathrm{BALB} / \mathrm{C}$ mice were immunized with the antigen and the spleen cells were fused with NS1 myloma cells at a ratio of $5: 1$ in the presence of $50 \%$ polyethylene glycol 4000. Fused cells were distributed to 96 wells in microculture plates and selected for binding activity by HAT medium, and culture supernatants were screened for binding activity by dot immunobinding assay under conditions where they bound to human thyroid microsomes but not to human thyroglobulin or kidney microsomes. Consequently, 7 wells were selected and cloned at least twice by limiting dilution. Seven clones compatible with the above conditions which secreted immunoglobulin G (IgG) class antibodies were finally expanded and injected intraperitoneally into $\mathrm{BALB} / \mathrm{C}$ mice to collect ascites fluid by Sephacryl S-300 gel filtration and DEAEcellulose chromatography and tested for their binding ability by micro-ELISA. The clone which produced an antibody with the highest inhibitory action on TPO was TM-Mo 3.

Preparation of Sepharose-bound $m A b$ and affinity column: The clone TM-Mo 3 was injected into $\mathrm{BALB} / \mathrm{C}$ mice to collect the ascites fluid containing the $m A b$. The $m A b$ was purified on a Protein- $A$ Sepharose column, and coupled to $\mathrm{CNBr}$ activated Sepharose $4 \mathrm{~B}$ according to the manufacturer's instructions. One milliliter beads coupled with $4 \mathrm{mg} \mathrm{mAb}$ are packed into a column $(6 \times 35$ $\mathrm{mm}$ ), and the column was washed with $20 \mathrm{ml}$ PBS.

\section{Determination of heme concentration}

The concentration of TPO was determined from the cyanide-difference spectrum [12], except that a newly established extinction coefficient of the peak minus trough, $85 \times 10^{3} \mathrm{M}^{-1} \mathrm{~cm}^{-1}$ [27], was employed. Small cuvettes $(0.45 \mathrm{ml}, 5 \mathrm{~mm}$ wide and $10 \mathrm{~mm}$ light path) were used.

Preparation of polyclonal anti-TPO antibodies and Western blotting

Anti-human TPO polyclonal antibodies were prepared as described previously [28]. SDS-PAGE and western blotting experiments were performed as reported [29].

\section{Determination of protein content}

Protein was determined by the method of Lowry et al. [30] with the bovine serum albumin as the standard.

\section{Results}

Starting with about $1 \mathrm{~g}$ tissue of each, the mitochondria-microsomes fractions were prepared and assayed for TPO activity. The proteinbased specific activity of each thyroid in experiment 1 varied from 3.76 to $55.0 \mathrm{mGU} / \mathrm{mg}$ protein and from 3.68 to $55.0 \mathrm{mIU} / \mathrm{mg}$ protein, the mean $\pm \mathrm{SD}(\mathrm{n}=10)$ being $24.5 \pm 17.3 \mathrm{mGU} / \mathrm{mg}$ protein and $21.8 \pm 16.3 \mathrm{mIU} / \mathrm{mg}$ protein. These values were similar to those obtained in the guaiacol assay and higher than those obtained in the iodide assay previously for normal thyroid (the mean value was $30.0 \mathrm{mGU} / \mathrm{mg}$ protein and $6.6 \mathrm{mIU} / \mathrm{mg}$ protein, $\mathrm{n}=10)[20]$. 


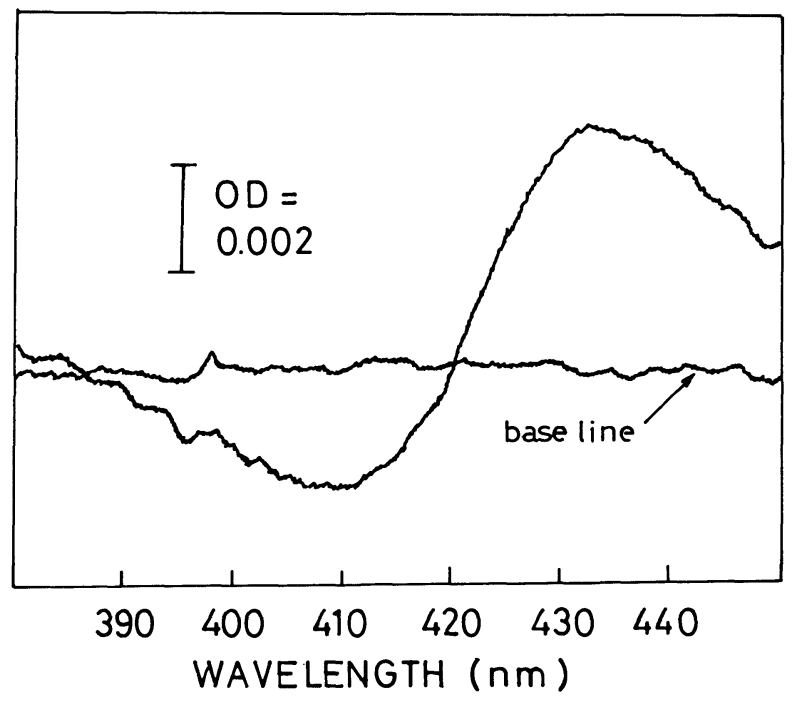

Fig. 1. Difference spectrum of TPO-cyanide complex. TPO preparation used in this experiment was from patient 2 in experiment 1 . Both cuvettes contained $80 \mu \mathrm{g}$ protein per $\mathrm{ml}(\mathrm{pH}$ 7.4). Potassium cyanide was added to the sample cuvette to make a concentration of $100 \mu \mathrm{M}$.

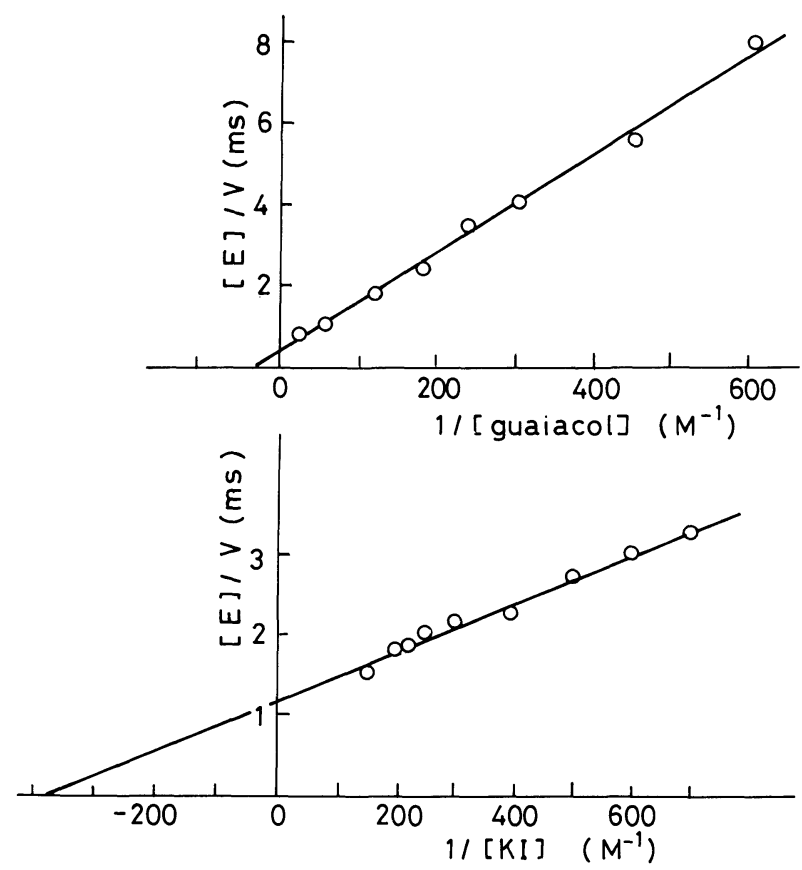

Fig. 2. Double-reciprocal plots of guaiacol oxidation (upper panel) and iodide oxidation (lower panel) catalyzed by TPO purified the thyroid of patient 2. The TPO concentrations used were $0.24-0.61 \mathrm{nM}$ (upper panel) and $0.12-0.30 \mathrm{nM}$ (lower panel).
TPO in the mitochondria-microsomes obtained from about $15 \mathrm{~g}$ of each thyroid from 14 patients was solubilized with cholate plus trypsin. Then it was purified by DEAE-cellulose chromatography and affinity chromatography. The final preparation each was subjected to determination of the heme concentration and the $\mathrm{Km}$ values for the second substrates, guaiacol and iodide. The former is based on the observation of the difference spectrum for TPO-CN versus TPO [12] and the latter, on the analysis of double reciprocal plots. Figs. 1 and 2 show some examples of these experiments.

In the latter figure, the intercepts of the line with the abscissa and the ordinate are $-1 / \mathrm{Km}$ and $[\mathrm{E}] / \mathrm{V}_{\max }$, respectively. Thus, the values for $\mathrm{Km}$ and $\mathrm{k}_{\text {cat }}\left(=\mathrm{V}_{\text {max }} /[\mathrm{E}]\right)$ were calculated and are shown in columns $\mathrm{b}$ and $\mathrm{c}$ in Table 2 . The values shown in column a are the values for peroxidase activity obtained under standard assay conditions divided by heme content. In the table, data for two groups, experiment 1 (10 patients) and experiment 2 (4 patients), are summarized. The values for $\mathrm{Pa} 8$ were discarded by Smirnoff's analysis. The data in the same group resemble each other as will be seen from the comparatively low coefficient of variation (the ratio of SD to the mean), but those in the two groups were somewhat different, especially the values obtained in the guaiacol assay. The cause of the difference will be discussed below.

\section{Discussion}

The procedure for TPO extraction and purification from a large amount of thyroid tissues has already been established [12-15], but a more efficient and less time-consuming method was required to fulfil the purpose of the present study to compare the heme-based activity of TPO preparation derived from each thyroid. To accomplish this, we re-examined each step in the purification procedures and finally employed the procedures described in Materials and Methods which include an effective solubilization with trypsin and cholate and two-step column treatment: ion exchange chromatography and immunoaffinity chromatography. By these procedures, we were able to isolate the enzyme with an $\mathrm{RZ}\left(\mathrm{A}_{412} / \mathrm{A}_{280}\right)$ of $0.1-0.3$ within $12 \mathrm{~h}$, starting with less than $15 \mathrm{~g}$ of 
Table 2. The values for (a) heme-based specific activity, (b) $\mathrm{Km}$ and (c) $\mathbf{k}_{c a t}$ of TPO purified from toxic diffuse goiters

\begin{tabular}{|c|c|c|c|c|c|c|}
\hline \multirow{2}{*}{$\begin{array}{l}\text { Patients } \\
\text { No. }\end{array}$} & \multicolumn{3}{|c|}{ Guaiacol assay } & \multicolumn{3}{|c|}{ Iodide assay } \\
\hline & $(a)^{a}$ & (b) & (c) & (a) & (b) & (c) \\
\hline \multicolumn{7}{|c|}{ Experiment 1} \\
\hline 1 & 0.44 & 1.23 & 214 & 0.83 & 1.42 & 145 \\
\hline 2 & 0.67 & 0.57 & 743 & 1.59 & 0.85 & 212 \\
\hline 3 & 0.34 & 0.37 & 424 & 1.71 & 2.30 & 359 \\
\hline 4 & 0.73 & 1.15 & 466 & 1.41 & 1.68 & 251 \\
\hline 5 & 0.43 & 0.33 & 517 & 2.54 & 1.76 & 381 \\
\hline 6 & 0.42 & 1.52 & 373 & 1.65 & 1.72 & 293 \\
\hline 7 & 0.35 & 1.14 & 308 & 1.48 & 2.41 & 306 \\
\hline $8^{\mathrm{b}}$ & $(2.58)$ & $(15.7)$ & (2174) & $(2.97)$ & $(2.83)$ & (609) \\
\hline 9 & 0.52 & 0.62 & 226 & 0.79 & 1.93 & 143 \\
\hline 10 & 0.62 & 0.90 & 305 & 1.25 & 1.51 & 184 \\
\hline Mean & 0.50 & 0.88 & 397 & 1.47 & 1.73 & 253 \\
\hline $\begin{array}{l} \pm \mathrm{SD} \\
(\mathrm{n}=9)\end{array}$ & 0.14 & 0.42 & 166 & 0.52 & 0.47 & 88 \\
\hline $\mathrm{CV}^{\mathrm{c}}$ & 0.28 & 0.48 & 0.42 & 0.35 & 0.27 & 0.35 \\
\hline \multicolumn{7}{|c|}{ Experiment 2} \\
\hline 11 & 3.03 & 41.7 & 3143 & 5.27 & 2.24 & 996 \\
\hline 12 & 2.51 & 45.0 & 3522 & 5.51 & 2.56 & 840 \\
\hline 13 & 3.23 & 100.8 & 5501 & 3.38 & 2.40 & 553 \\
\hline 14 & 4.17 & 85.3 & 6007 & 3.87 & 1.76 & 636 \\
\hline Mean & 3.25 & 68.9 & 4543 & 4.51 & 2.24 & 756 \\
\hline $\begin{array}{l} \pm \mathrm{SD} \\
(\mathrm{n}=4)\end{array}$ & 0.69 & 29.4 & 1421 & 1.04 & 0.35 & 200 \\
\hline $\mathrm{CV}$ & 0.21 & 0.43 & 0.31 & 0.23 & 0.16 & 0.26 \\
\hline
\end{tabular}

a: (a), (b) and (c) stand for heme-based specific activity (GU or IU/nmole heme), Km $(\mathrm{mM})$ and $\mathrm{k}_{\mathrm{cat}}\left(\mathrm{s}^{-1}\right)$, respectively. b: The data for $\mathrm{Pa} 8$ in parentheses were excluded in the calculation of the mean \pm SD by Smirnoff's analysis. c: CV (coefficients of variation) means the ratio of $\mathrm{SD}$ to the mean.

thyroid tissue. It has been reported that the almost pure TPO preparation had an RZ of $0.55-0.6$ [13, 19]. Thus, the purity of the TPO preparations obtained here was estimated to be $15-50 \%$.

The heme concentration in the final preparation was determined by the method which employs a cyanide difference spectrum $[12,26]$, since the concentration was so low (below $1 \mu \mathrm{M}$ ) that determination by the usual method (measuring the absorbance at the Soret band, i.e. $\mathrm{A}_{412} / \varepsilon_{413}$ ) tended to cause some systematic errors due to slight turbidity in the solution.

After observation of the cyanide difference spectrum, the remaining samples of purified preparation were used for kinetic studies. As Table 2 shows, higher activities were always found in experiment 2 than in experiment 1 , especially in the guaiacol assay. In the case of experiment 1 , the homogenization of the tissues was started late in the morning, and the measurement of kinetics was postponed to the next day, with the sample being frozen until the measurement. The tissues in experiment 2 were subjected to homogenization early in the morning and the activity could be measured immediately after the final step of purification. It is therefore likely that the freezingthawing of the enzyme with extremely low concentrations in the case of experiment 1 might have decreased its activity, and this may be the main cause of the difference between the two groups in kinetic data. The loss of activity in the iodide assay was less than that in the guaiacol assay. TPO is known to have two binding sites for the second substrates, one for iodide and the other for aromatic substrates $[11,16]$, and it is possible that these sites differ in stability. 
As described above, the TPO activities in experiment 1 seem to be more or less impaired, and the levels of heme-based specific activities of TPO in toxic diffuse goiters may be represented by the activities of experiment 2. It is noteworthy that these are several times higher than those of porcine TPO previously reported [31]. It is not yet determined, however, whether the heme-based specific activities of toxic diffuse goiter's TPO are equal to those of normal human thyroid TPO, although it is highly probable in view of the results of cloning experiments $[32,33]$. In addition, all the samples of experiment 1 and experiment 2 showed a band at approximately $100 \mathrm{kDa}$ on western blotting as in the case of normal human thyroid tissues (not shown).

In the present paper, the degree of divergence of data in one group was expressed by the use of the coefficients of variation, $\mathrm{CV}$. The $\mathrm{CV}$ values for the heme-based specific activities of purified TPO, 0.28 and 0.21 for experiment $1(n=9)$ and experiment $2(n=4)$, respectively, which should theoretically converge to zero, are considered to reflect some variation in the determination of activity and protein content. On the other hand, the $\mathrm{CV}$ value for protein-based specific activity of
TPO in the mitochondria-microsomes was 0.66 , which is higher than that in heme-based specific activity. The individual difference of the proteinbased specific activity in the mitochondriamicrosomes may be therefore ascribed to, in addition to experimental errors, some variation in such a factor as TPO content per unit tissue. However, these individual differences were generally small, as in the case of normal thyroid tissues [22]. On the other hand, both toxic diffuse goiters and normal tissues were similar as to the proteinbased TPO specific activities of mitochondriamicrosomes. It is therefore considered that the remarkable increase in TPO activity in toxic diffuse goiters is mostly due to the hyperplasia in thyroid tissues with almost the same TPO content per unit tissue.

\section{Acknowledgments}

The authors are grateful to Dr. K. Ito (Ito Hospital, Tokyo) and Dr. K. Kuma (Kuma Hospital, Kobe) for supplying thyroids of patients with toxic diffuse goiters, and Koichi Sato (Daiichi Pharmaceutical Co.) for helpful discussion.

\section{References}

1. Nagasaka A, Hidaka H, Ishizuki Y (1975) Studies on human iodide peroxidase: its activity in various thyroid disorders. Clin Chim Acta 62: 1-4.

2. Valenta LJ (1976) Thyroid peroxidase, thyroglobulin, cAMP and DNA in human thyroid. J Clin Endocrinol Metab 43: 466-469.

3. Fragu P, Nataf BM (1977) Human thyroid peroxidase activity in benign and malign thyroid disorders. J Clin Endocrinol Metab 45: 1089-1096.

4. Nagataki S, Uchiyama $H$, Ikeda $H$, Kuzuya N, Masuyama Y, Kumagai LF, Ito K (1977) Iodinating activity of thyroid tissue in toxic diffuse goiter. $J$ Clin Invest 59: 723-729.

5. Neary JT, Nakamura C, Davidson B, Soodak M, Vickery AL, Maloof F (1978) Studies on the membrane-associated nature of human thyroid peroxidase: a difference in the solubility of the enzyme from benign and malignant thyroid tissues. J Clin Endocrinol Metab 46: 791-799.

6. Mizukami Y, Matsubara F (1981) Correlation between thyroid peroxidase activity and histopathological and ultrastructural changes in various thyroid diseases. Endocrinol Japon 28: 381-389.

7. Takamatsu J, Hosoya T, Naito N, Yoshimura H,
Kohno Y, Tarutani O, Kuma K, Sakane S, Takeda K, Mozai T (1988) Enhanced thyroid iodine metabolism in patients with triiodothyroninepredominant Graves' disease. J Clin Endocrinol Metab 66: 147-152.

8. Yamashita H, Noguchi S, Murakami N, Moriuchi A, Hodo M, Yokoyama S, Mochizuki Y, Noguchi A, Nakayama I (1984) Ultrastructural localization of endogenous peroxidase in the human thyroid gland under normal and hyperfunctioning conditions. Acta Pathol Jpn 34: 553-561.

9. Suzuki S, Yamamoto N, Nishii T, Hirakawa S, Ota $\mathrm{Z}$ (1987) Sebcellular localization of human thyroid microsomal antigens and its relation to thyroidal peroxidase. J Clin Electron Microscopy 20: 5-6.

10. DeGroot LJ, Niepomniszcze H (1977) Biosynthesis of thyroid hormone: basic and clinical aspects. Metabolism 26: 665-718.

11. Nunez J, Pommier J (1982) Formation of thyroid hormones. Vitam Horm 39: 175-229.

12. Hosoya T, Morrison M (1967) The isolation and purification of thyroid peroxidase. J Biol Chem 242: 2828-2836.

13. Rawitch AB, Taurog A, Chernoff SB, Dorris ML 
(1979) Hog thyroid peroxidase: physical, chemical, and catalytic properties of the highly purified enzyme. Arch Biochem Biophys 194: 244-257.

14. Neary JT, Soodak M, Maloof F (1984) Iodination by thyroid peroxidase. Method Enzymol 107: 445-475.

15. Ohtaki S, Nakagawa H, Nakamura S, Nakamura M, Yamazaki I (1985) Characterization of hog thyroid peroxidase. $J$ Biol Chem 260: 441-448.

16. Kohno Y, Hiyama Y, Shimojo N, Niimi H, Nakajima H, Hosoya T (1986) Autoantibodies to thyroid peroxidase in patients with chronic thyroiditis: effect of antibody on enzyme activities. Clin Exp Immunol 65: 534-541.

17. Kotani H, Ohtaki S, Nakamura M, Yamazaki I (1985) Purification of thyroid peroxidase by monoclonal antibody-assisted immunoaffinity chromatography. Biochem Biophys Res Commun 127: 8-14.

18. Czarnocka B, Ruf J, Ferrand M, Carayon P, Lissitzky S (1985) Purification of the human thyroid peroxidase and its identification as the microsomal antigen involved in autoimmune thyroid diseases. FEBS Lett 190: 147-152.

19. Ohtaki S, Kotani T, Nakamura Y (1986) Characterization of human thyroid peroxidase purified by monoclonal antibody-assisted chromatography. $J$ Clin Endocrinol Metab 63: 570-576.

20. Hirakawa S, Mizushima K, Shimizu I, Sunada M, Suzuki S, Ota Z (1986) Production of monoclonal antibodies to human thyroid microsome antigens. In: Medeiros-Neto G, Gaitan E (eds) Frontier in Thyroidology. Plenum Med Pub Co, NY, vol 2: 1415-1419.

21. Takamatsu J, Takeda K, Katayama S, Sakane S, Morita S, Kuma K, Ohsawa N (1992) Epithelial hyperplasia and decreased colloid content of the thyroid gland in triiodothyronine-predominant Graves' disease. J Clin Endocrinol Metab 75 (In press).

22. Hosoya T, Sato I, Hiyama Y, Yoshimura H, Niimi $\mathrm{H}$, Tarutani $\mathrm{O}$ (1985) An improved assay method for thyroid peroxidase applicable for a few milligrams of abnormal human thyroid tissues. $J$ Biochem (Tokyo) 98: 637-647.
23. Hosoya $T$ (1960) Turnip peroxidase II. The reaction mechanisms of turnip peroxidase $\mathrm{Al}, \mathrm{A} 2$ and D. J Biochem (Tokyo) 47: 794-803.

24. Hosoya T (1960) Turnip peroxidase IV. The effect of $\mathrm{pH}$ and temperature upon the rate of reaction. $J$ Biochem (Tokyo) 48: 178-189.

25. Hosoya T (1963) Effect of various reagents including antithyroid compounds upon the activity of thyroid peroxidase. J Biochem (Tokyo) 53: 381-388.

26. Hosoya T (1976) Thyroid peroxidase. In: Kagawa Y, Kajiro Y, Sato R, Hayaishio, Yagi K (eds) Seikagaku Jikken Koza. vol. 12: 625-631.

27. Hosoya T (1991) Thyroid peroxidase. In: (Hosoya $\mathrm{T}$ (ed) Thyroid Hormones and Related Proteins. Asakura Shoten, Tokyo: 57-81.

28. Watanabe K, Nakamura A, Suzuki N, Futaesaku Y, Hosoya T (1991) In vivo Effect of thyrotropin on intracellular translocation of thyroid peroxidase in rat thyroid cells by an indirect immunofluorescence method. Endocrinol Japon 38: 89-96.

29. Suzuki N, Kobayashi M, Sakata K, Suzuki T, Hosoya T (1991) Synergistic stimulatory effect of glucocorticoid, EGF and insulin on the synthesis of ribosomal RNA and phosphorylation of nucleolin in primary cultured rat hepatocytes. Biochim Biophys Acta 1092: 367-375.

30. Lowry OH, Rosebrough NJ, Farr AL, Randall RJ (1951) Protein measurement with Folin phenol reagent. J Biol Chem 193: 265-275.

31. Hosoya T, Morrison M (1967) A study of the hemoproteins of thyroid microsomes with emphasis on the thyroid peroxidase. Biochemistry 6 : 1021-1026.

32. Kimura S, Kotani T, McBride OW, Umeki K, Hirai K, Nakayama T, Ohtaki S (1987) Human thyroid peroxidase: complete cDNA and protein sequence, chromosome mapping, and identification of two alternately spliced mRNAs. Proc Natl Acad Sci USA 84: 5555-5559.

33. Magnusson RP, Chazenbalk GD, Gestauts J, Seto P, Filetti S, DeGroot LJ, Rapoport B (1987) Molecular cloning of the complementary deoxyribonucleic acid for human thyroid peroxidase. Mol Endocrinol 1: $856-861$. 